\title{
Troglitazone Inhibits Vascular Smooth Muscle Cell Growth and Intimal Hyperplasia
}

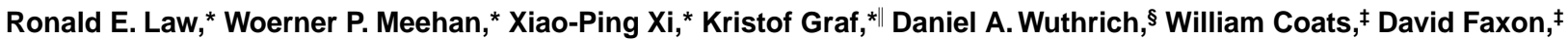 \\ and Willa A. Hsueh* \\ *University of Southern California School of Medicine, Department of Medicine, Division of Endocrinology, Diabetes and Hypertension, \\ and Division of Cardiology, Los Angeles, California 90033; ${ }^{\S}$ Department of Medicine, Division of Cardiology, University of Washington, \\ Seattle, Washington 98195; and ${ }^{\|}$Department of Medicine/Cardiology, Virchow Klinikum d.HU Berlin, and German Heart Institute, \\ Berlin, Germany
}

\begin{abstract}
Vascular smooth muscle cell (VSMC) proliferation and migration are responses to arterial injury that are highly important to the processes of restenosis and atherosclerosis. In the arterial balloon injury model in the rat, platelet-derived growth factor (PDGF) and basic fibroblast growth factor (bFGF) are induced in the vessel wall and regulate these VSMC activities. Novel insulin sensitizing agents, thiazolidinediones, have been demonstrated to inhibit insulin and epidermal growth factor-induced growth of VSMCs. We hypothesized that these agents might also inhibit the effect of PDGF and bFGF on cultured VSMCs and intimal hyperplasia in vivo. Troglitazone $(1 \mu \mathrm{M})$, a member of the thiazolidinedione class, produced a near complete inhibition of both bFGF-induced DNA synthesis as measured by bromodeoxyuridine incorporation $(6.5 \pm 3.9$ vs. $17.6 \pm 4.3 \%$ cells labeled, $P<0.05$ ) and $c$-fos induction. This effect was associated with an inhibition (by $73 \pm 4 \%, P<0.01$ ) by troglitazone of the transactivation of the serum response element, which regulates $c$-fos expression. Inhibition of $c$-fos induction by troglitazone appeared to occur via a blockade of the MAP kinase pathway at a point downstream of MAP kinase activation by MAP kinase kinase. At this dose, troglitazone also inhibited PDGF-BB-directed migration of VSMC (by $70 \pm 6 \%, P<0.01$ ). These in vitro effects were operative in vivo. Quantitative image analysis revealed that troglitazone-treated rats had $62 \%(P<0.001)$ less neointima/media area ratio $14 \mathrm{~d}$ after balloon injury of the aorta compared with injured rats that received no troglitazone. These results suggest troglitazone is a potent inhibitor of VSMC proliferation and migration and, thus, may be a useful agent to prevent restenosis and possibly atherosclerosis. (J. Clin. Invest. 1996. 98:1897-1905.) Key words: restenosis • plateletderived growth factor $\bullet$ basic fibroblast growth factor $\bullet c$-fos - MAP kinase
\end{abstract}

\section{Introduction}

Migration and proliferation of vascular smooth muscle cells (VSMCs) $^{1}$ are critical events in the development of restenosis

\footnotetext{
Address correspondence to Willa A. Hsueh, M.D., USC Medical Center, 1200 N. State Street, Room 8250, Los Angeles, CA 90033. Phone: 213-342-3524; FAX: 213-342-3528.

Received for publication 20 March 1996 and accepted in revised form 13 August 1996.
}

J. Clin. Invest.

(c) The American Society for Clinical Investigation, Inc. 0021-9738/96/10/1897/09 \$2.00

Volume 98, Number 8, October 1996, 1897-1905 and in the progression of atherosclerosis (1). In the rat balloon injury model resulting in arterial intima hyperplasia, plateletderived growth factor (PDGF) and basic fibroblast growth factor (bFGF) are important regulators of VSMC behavior through their well-defined respective actions as a potent chemoattractant (2-5) and a strong mitogen $(6,7)$. These factors, while not usually expressed in the normal artery, are upregulated after endothelial cell injury either after angioplasty or due to atherosclerosis (8-10). Administration of these growth factors enhances vascular injury after angioplasty in the rat $(4,6)$, while injection of antibodies or the use of antisense technology to block signal transduction by either of these growth factors severely inhibits postinjury intimal hyperplasia in the rat and restenosis in the pig, suggesting that VSMC growth plays an important role in these pathologies $(3,7,11,12)$. There are no substances known to prevent restenosis in humans.

Thiazolidinediones are novel insulin-sensitizing agents that have been shown to significantly reduce hyperinsulinemia in insulin-resistant animals and humans and to reduce hyperglycemia in diabetic models including humans. They improve insulin-mediated glucose uptake into skeletal muscle (13-17). These agents are currently in clinical trials for both the treatment and prevention of non-insulin-dependent diabetes mellitus (NIDDM). An early study demonstrated that the thiazolidinedione analogue, pioglitazone, inhibited insulin, epidermal growth factor (EGF), and serum-induced growth of cultured arterial VSMCs (18). However, nothing is known about the mechanisms by which these agents inhibit VSMC growth or whether this action is functionally significant in vivo. The purpose of the present investigation was to determine the effect of troglitazone, another member of the thiazolidinedione family, on: bFGF-induced VSMC growth and the mechanism of this effect; PDGF-BB-induced VSMC migration; and VSMC intimal hyperplasia after endothelial injury in the rat.

\section{Methods}

Materials. Materials were obtained from the following suppliers. PDGF-BB, DMEM, FBS, bromodeoxyuridine (BrdU), alkaline phosphatase-conjugated anti-mouse IgG antibody, monoclonal antibody against smooth muscle $\alpha$-actin, and myelin basic protein (MBP) were from Sigma Chemical Co. (St. Louis, MO). Culture plastic ware was from Falcon Labware (Lincoln Park, NJ). bFGF was from R\&D Systems (Minneapolis, MN). Mouse anti-BrdU monoclonal antibody was from Zymed Laboratories, Inc. (South San Francisco, CA). Troglitazone and PD 98059 were a generous gift from Parke-Davis (Ann

1. Abbreviations used in this paper: $\mathrm{BrdU}$, bromodeoxyuridine; $\mathrm{CAD}$, coronary artery disease; CAT, chloramphenicol acetyl transferase; HPFs, high power fields; MBP, myelin basic protein; MEK, MAP kinase/ERK kinase; NIDDM, non-insulin-dependent diabetes mellitus; SRE, serum response elements; VSMC, vascular smooth muscle cell. 
Arbor, MI). The serum response element (SRE)-chloramphenicol acetyl transferase (CAT) plasmids were the kind gift of Dr. Axel Schonthal (Department of Microbiology, USC) and contained two copies of the $c$-fos SRE as oligonucleotides inserted upstream of the thymidine kinase minimal promoter in a vector with a pBLCAT backbone.

The pSG Gal-Elk-1, pSG Gal-Elk-1 $\Delta$ A, and GAL4-CAT plasmids were the kind gift of Dr. Peter Shaw (Max Planck Institute, Freiburg, Germany). The mutant expression vector pSG Gal-Elk$1 \Delta \mathrm{A}$ is derived from pSG Gal-Elk-1 by deleting the ApaI fragment which deletes Elk-1 amino acids 254-424 that contain multiple MAP kinase phosphorylation sites (19). The reporter plasmid GAL4-CAT contains four yeast GAL4 sites upstream of the thymidine kinase promoter linked to CAT (19).

Cell culture and treatment with growth factors and troglitazone. Rat aortic smooth muscle cells were prepared from thoracic aorta of 2-3-mo-old Sprague-Dawley rats using the explant technique. The cells were cultured in DMEM containing $10 \%$ FBS, $100 \mathrm{U} / \mathrm{ml}$ penicillin, $100 \mu \mathrm{g} / \mathrm{ml}$ streptomycin, and $200 \mathrm{mM} \mathrm{L}$-glutamine. The purity and identity of the smooth muscle cell cultures were verified by using a monoclonal antibody against smooth muscle $\alpha$-actin. For all experiments, early passaged (four or less) rat VSMCs were grown to 60$70 \%$ confluency and made quiescent by serum starvation ( $0.4 \%$ FBS $)$ for at least $16 \mathrm{~h}$. When used, troglitazone was added $30 \mathrm{~min}$ before the addition of growth factors. For all data shown, each individual experiment represented in the $n$ value was performed using an independent preparation of VSMCs.

Measurement of DNA synthesis. Incorporation of the thymidine analogue BrdU was measured to determine the effect of growth factors and troglitazone on DNA synthesis. VSMCs were plated at $3.0 \times 10^{4}$ cells on 24 -well plates in DMEM and $10 \%$ FBS for $48 \mathrm{~h}$. After serum starvation for $48 \mathrm{~h}$ in DMEM, cells were stimulated with growth factors in the presence or absence of inhibitors for the next $20 \mathrm{~h}$. Then $15 \mu \mathrm{M}$ BrdU was added, and the incubation was continued for another $4 \mathrm{~h}$. After several washes with PBS, cells were fixed with methanol $\left(10 \% \mathrm{vol} / \mathrm{vol}\right.$ for $10 \mathrm{~min}$ at $\left.4^{\circ} \mathrm{C}\right)$, followed by incubation in $1 \mathrm{~N} \mathrm{HCl}$ for $2 \mathrm{~h}$. Mouse anti-BrdU mAb (diluted 1:400; Zymed Laboratories, Inc.) in $2 \%$ BSA-PBS was incubated overnight at $4{ }^{\circ} \mathrm{C}$, followed by AP-conjugated goat anti-mouse IgG antibody (diluted 1:1,000) for $1 \mathrm{~h}$ at room temperature. Dako fast red substrate system (Dako Corp., Carpinteria, CA) was used as chromogen and counterstaining was performed with hematoxylin. Cell nuclei which incorporated BrdU appeared red and were counted in four to six different high power fields (HPFs) (magnification of 200) per well and related to total cell number. Alternatively, DNA synthesis was measured using a commercial kit that detects BrdU incorporation by ELISA (Boehringer Mannheim, Indianapolis, IN).

MTT assay for cellular viability. A modified colorimetric assay based on the selective ability of living cells to reduce the yellow salt MTT (3-[4,5-dimethylthiozol-2-yl]-2,5 diphenyl tetrazolium bromide) to formazan was used to quantitate cell viability. After the culture period of $48 \mathrm{~h}$ in the presence of troglitazone, MTT at $5 \mathrm{mg} / \mathrm{ml}$ (Sigma Chemical Co.) was added to each well for a period of $4 \mathrm{~h}$. After formation of the formazan crystals, the culture medium supernatant was removed from the wells without disruption of the formazan precipitate. The formazan crystals were then dissolved in $150 \mu \mathrm{l} /$ well DMSO (DMSO 100\%; Sigma Chemical Co.). The absorbance was measured at $570 \mathrm{~nm}$ using a microplate spectrophotometer (MR700; Dynatech Laboratories Inc., Chantilly, VA) interfaced with an Apple Macintosh PC computer. It has been shown previously that viable cell numbers correlate with optical density as determined by the MTT assay $(20,21)$.

RNA isolation and Northern blot analysis. RNA was harvested using a guanidinium-sodium acetate phenol-chloroform method (22). Total RNA $(20 \mu \mathrm{g})$ was electrophoresed through $1 \%$ agarose gels containing formaldehyde, transferred to charged nylon membranes (MSI, Westboro, MA), and cross-linked in a Stratalinker (Stratagene, La Jolla, CA). cDNA probes $\left({ }^{32} \mathrm{P}\right.$-labeled using a random primer method) were: $c$-fos and CHO-B, a cDNA originally isolated from Chinese hamster ovary cells that corresponds to an mRNA ubiquitously expressed in mammalian tissues which does not exhibit regulation as a function of growth or development (23). The intensity of CHO-B signals in individual lanes serves as an internal control for equal loading of gels and transfer to membranes.

Transfections. VSMCs were transfected with: 10-15 $\mu \mathrm{g}$ of SRECAT reporter plasmid, or $7.5 \mu \mathrm{g}$ of Gal-Elk-1 expression vector and $7.5 \mu \mathrm{g}$ of GAL4-CAT reporter plasmid, or $7.5 \mu \mathrm{g}$ of the mutant GalElk-1 $\Delta$ A expression vector and $7.5 \mu \mathrm{g}$ of Gal4-CAT reporter plasmid and $5 \mu \mathrm{g}$ of pCH110 (SV40 $\beta$-galactosidase reference plasmid) using a calcium phosphate transient transfection kit (Stratagene). After transfection, cells were starved for $16 \mathrm{~h}$ before stimulation with bFGF for $6 \mathrm{~h}$. Troglitazone was added $30 \mathrm{~min}$ before the addition of growth factor. Lysates were prepared and normalized for protein content using the Lowry method. CAT and $\beta$-galactosidase assays were performed using standard methods $(24,25)$. All experiments were performed in duplicate and repeated at least three times to ensure reproducibility. CAT activities were corrected for transfection efficiency by assaying extracts for $\beta$-galactosidase activity.

In-gel kinase. To measure MAP kinase activity, cells are lysed in a buffer containing $50 \mathrm{mM}$ sodium pyrophosphate, $50 \mathrm{mM} \mathrm{NaF}, 50 \mathrm{mM}$ $\mathrm{NaCl}, 5 \mathrm{mM}$ EDTA, $5 \mathrm{mM}$ EGTA, $100 \mu \mathrm{g} / \mathrm{ml}$ leupeptin, then flash frozen on a dry ice-ethanol bath. After allowing the cells to thaw, cells are scraped off the dish and centrifuged at $14,000 \mathrm{rpm}\left(4^{\circ} \mathrm{C}\right.$ for $30 \mathrm{~min}$ ), and protein concentrations are determined using the Bradford protein assay (Bio-Rad Laboratories, Richmond, VA). Equal amounts of proteins $(5-10 \mu \mathrm{g})$ are separated by SDS-PAGE through a gel containing $0.4 \mathrm{mg} / \mathrm{ml} \mathrm{MBP}$. The gel is then incubated twice in buffer $\mathrm{A}(50 \mathrm{mM}$ Hepes, $\mathrm{pH} 7.4$, and $5 \mathrm{mM} \beta$-mercaptoethanol) containing $20 \%$ isopropyl alcohol for $30 \mathrm{~min}$, once in buffer A for $1 \mathrm{~h}$, twice in buffer A containing $6 \mathrm{M}$ guanidine $\mathrm{HCl}$ for $30 \mathrm{~min}$, twice in buffer A containing $0.04 \%$ Tween 20 at $4^{\circ} \mathrm{C}$ for 16 and $2 \mathrm{~h}$, once in buffer A containing $100 \mu \mathrm{M} \mathrm{Na}_{3} \mathrm{VO}_{4}$, and $10 \mathrm{mM} \mathrm{MgCl}$ at $30^{\circ} \mathrm{C}$ for $30 \mathrm{~min}$. The reaction is terminated by washing the gel five to eight times in fixative solution containing $10 \mathrm{mM}$ sodium pyrophosphate and $5 \%$ trichloroacetic acid for $15 \mathrm{~min}$. The gel is dried and subjected to autoradiography.

Migration. VSMC migration was examined in Transwell cell culture chambers using a gelatin-treated polycarbonate membrane with $8-\mu \mathrm{m}$ pores in 24-well plates (Costar Corp., Cambridge, MA). Preconfluent rat aortic smooth muscle cells were suspended in DMEM/ $0.4 \%$ FBS to a concentration of $3.0 \times 10^{5}$ cells $/ \mathrm{ml}$. Cells were pretreated with troglitazone $(1-20 \mu \mathrm{M})$ or vehicle for $30 \mathrm{~min}$ at $37^{\circ} \mathrm{C}$. DMEM/ 0.4\% FBS $(0.6 \mathrm{ml})$ with or without PDGF-BB $(20 \mu \mathrm{g} / \mathrm{ml})$ was added to the lower compartment. $0.1-\mathrm{ml}$ cell suspension (final: 30,000 cells/well, diameter $6.5 \mathrm{~mm}$ ) were added to the upper compartment with or without troglitazone and cells were then incubated at $37^{\circ} \mathrm{C}\left(95 \%\right.$ air $\left./ 5 \% \mathrm{CO}_{2}\right)$. After $4 \mathrm{~h}$, the filters were fixed with methanol $\left(10 \mathrm{~min}\right.$ at $\left.4^{\circ} \mathrm{C}\right)$, followed by counterstaining with hematoxylin. The number of VSMCs per $320 \times$ HPF that migrated to the lower surface of the filters was determined microscopically. Four randomly chosen HPFs were counted per filter. Experiments were performed in triplicate.

Balloon injury and morphometric analysis of intimal thickening. Male Sprague-Dawley rat weighing 280-300 grams were divided into two groups ( $n=4 /$ group) and placed on powdered chow. One group received a 4-gram troglitazone/kg chow supplement, while the other group's diet was unchanged. After $3 \mathrm{~d}$, all animals received balloon injury to the aorta extending caudal to the renal artery and rostral to the left main carotid artery. Balloon-catheter injury was induced during ketamine (35 mg/kg, intramuscularly) and xylazine anesthesia. Using sterile technique, the left common carotid was exposed and an incision was made allowing the retrograde introduction of a Fogarty (No. 2F French) catheter $(26,27)$ into the aorta. The catheter was directed away from the heart and the balloon was positioned just above the renal arteries. The balloon was distended with sufficient saline to create resistance and then dragged five times through the aortic lu- 
men in one direction to the takeoff of the carotid artery at the aortic arch. The catheter was removed, the carotid was ligated, and the wound was closed. Animals received penicillin $(15,000 \mathrm{U}$, intramuscularly) immediately before the surgery.

VSMC proliferation was examined $2 \mathrm{~d}$ after injury by administration of $\mathrm{BrdU}$ (a thymidine analogue, $10 \mathrm{mM}, 10 \mathrm{ml} / \mathrm{kg}$ via the jugular vein) to animals $3 \mathrm{~h}$ before time of killing (28). At autopsy, animals were perfused with $10 \%$ buffered formalin. The entire aorta and a section of small intestine (positive control) was removed, embedded in paraffin, cut in cross sections (four sections/animal), and immunohistologically stained with a monoclonal antibody against BrdU. The sections were counterstained with methyl green. Cells staining for $\mathrm{BrdU}$ and therefore undergoing division, as well as total cells, in the intima were counted using a $\times 400$ microscope. The percentage of total cells staining positive was calculated. $14 \mathrm{~d}$ after balloon injury, animals were killed with an overdose of pentobarbital $(120 \mathrm{mg} / \mathrm{kg})$ and subjected to whole body perfusion with $4 \%$ paraformaldehyde. The aortae were removed, cut into cross-sectional segments, and embedded in paraffin. Sections $5 \mu \mathrm{m}$ thick $(n=5$ per animal) were stained with hematoxylin and eosin. Morphometric analyses were conducted using an Olympus microscope with a $\times 4$ objective and a video camera mounted on the eyepiece tube (27). The image was displayed in a high resolution monitor and digitized by a video frame grabber (PCVISION Plus, Imaging Technology) in an IBM compatible computer. The morphometric analysis program OPTIMAS (Bioscan Inc.) was used to determine the area of the intima. This was defined as the area circumscribed by the internal elastic lamina minus the area within the lumen. The morphometric histologic analyses were performed by two experienced investigators who were blinded to the protocol group and treatment.

Statistics. ANOVA, paired, or unpaired $t$ tests were performed for statistical analysis, as appropriate. $P$ values $<0.05 \%$ were considered to be statistically significant. Data are expressed as mean \pm SEM.

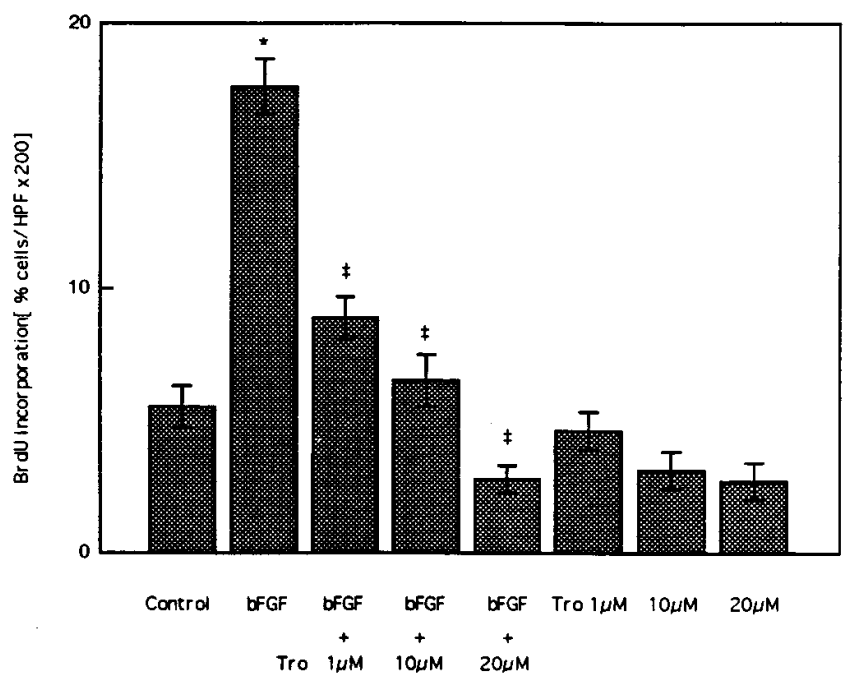

Figure 1. Troglitazone inhibits bFGF-stimulated DNA synthesis by VSMCs. Cells were made quiescent by incubation in DMEM containing $0.4 \%$ FBS for $48 \mathrm{~h}$. Quiescent VSMCs were stimulated by treatment with $20 \mathrm{ng} / \mathrm{ml} \mathrm{bFGF}$. Cells were preincubated with 1,10 , or $20 \mu \mathrm{M}$ troglitazone for $30 \mathrm{~min}$ before the addition of bFGF. To measure DNA synthesis, cells were stimulated with bFGF for $24 \mathrm{~h} ; 15 \mu \mathrm{M}$ $\mathrm{BrdU}$ was present for the final $4 \mathrm{~h}$. Incorporation of BrdU was determined as described in Methods. The percentage of cells incorporating $\mathrm{BrdU}$ is expressed as mean $\pm \operatorname{SEM}\left(n=6-8,{ }^{*} P<0.01\right.$ vs. Control, ${ }^{\ddagger} P<0.05$ vs. bFGF alone).

\section{Results}

Troglitazone inhibits FGF-induced DNA synthesis in VSMCs. At $1 \mu \mathrm{M}$ troglitazone, $8.8 \pm 3.9 \%(n=8)$ of cells in the preparations were BrdU positive as compared with $17.6 \pm 4.3 \%$ BrdU positive $(P<0.05)$ treated with bFGF alone. A nearly total inhibition of DNA synthesis (Fig. 1) was observed in the presence of $10 \mu \mathrm{M}$ troglitazone, with which only $6.5 \pm 4.0 \%$ of cells stained positively for BrdU as compared with cells stimulated with bFGF alone $(P<0.01)$. Background DNA synthesis in starved unstimulated control VSMCs showed $5.5 \pm 3.4 \%$ BrdU-positive cells $(n=6-8)$. When quiescent cells were treated with 1 and $10 \mu \mathrm{M}$ troglitazone for $48 \mathrm{~h}$ in the absence of bFGF, no significant difference was observed in the fraction of BrdU-positive cells (Fig. 1), suggesting that troglitazone was not toxic to the cells. Similar results were obtained when DNA synthesis was measured by $\left[{ }^{3} \mathrm{H}\right]$ thymidine incorporation (data not shown). These results reveal that troglitazone can inhibit mitogenic signal transduction by bFGF in cultured VSMCs.

To confirm that troglitazone was not cytotoxic for VSMCs, cell viability was assessed using 3-[4,5-dimethylthiazol-2-yl]2,5-diphenyltetrazolium bromide assay (MTT) that measures mitochondrial function. The data in Fig. 2 show that troglitazone in the range of $1-20 \mu \mathrm{M}$ has no effect on cell viability as indicated by equivalent mitochondrial activity in control and troglitazone-treated VSMCs after $48 \mathrm{~h}$. Troglitazone had no permanent effect on VSMCs since they resumed normal growth after the inhibitor was washed out and cells were refed with media lacking troglitazone (data not shown).

Troglitazone inhibits the induction of c-fos by bFGF. A transient induction of $c$-fos mRNA expression accompanies the stimulation of quiescent cells to proliferate by a variety of growth factors, including bFGF $(28 \mathrm{a}, 29)$. Troglitazone concentrations as low as $1 \mu \mathrm{M}$ totally blocked bFGF-induced $c$-fos mRNA expression (Fig. 3). The autoradiogram depicted is representative of the results observed in four independent experiments. Significant inhibition of both DNA synthesis and $c$-fos induction occurred at $1 \mu \mathrm{M}$ troglitazone, suggesting that

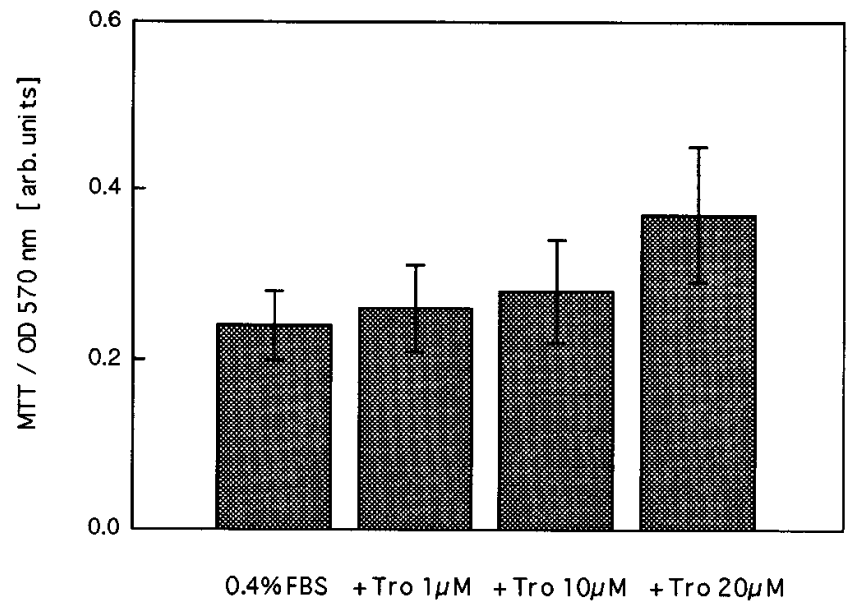

Figure 2. Troglitazone does not affect the viability of VSMCs. Cells were made quiescent by shifting them from 10 to $0.4 \%$ FBS for $16 \mathrm{~h}$. Quiescent cells were then treated with 1,10 , or $20 \mu \mathrm{M}$ troglitazone for an additional $48 \mathrm{~h}$ at which time an MTT assay was performed. Values represent the mean \pm SEM of quintuplicate wells from three independent experiments. 


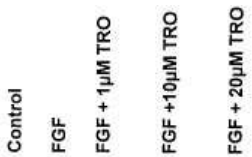

28s

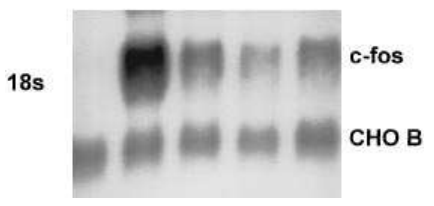

СHO B

lane and blots were hybridized with labeled cDNA inserts for
$c$-fos and CHO-B. Hybridization to CHO-B, an mRNA

from a housekeeping gene, indicates that there was equivalent loading of RNA in different lanes. The autoradiogram shown is representative of four independent time course experiments that were performed.

its antiproliferative effect in VSMCs may result from its ability to inhibit the induction of the important early growth response gene $c$-fos, which occurs when cells undergo transition from quiescence to the proliferative state.

Troglitazone blocks transactivation of the SRE. Transcriptional activation of the $c$-fos gene by bFGF is mediated, at least in part, through the interaction of transcription factors with an SRE located in the $c$-fos $5^{\prime}$-flanking DNA (28a, 29). To determine if the inhibition of bFGF-induced $c$-fos mRNA expression by troglitazone reflected diminished transcriptional activation of $c$-fos through its SRE, 2x-SRE-CAT reporter plasmids were transiently transfected into VSMCs. In the absence of bFGF, basal SRE-directed CAT activity was twofold greater than that detected in lysates from mock-transfected cells. Addition of $20 \mathrm{ng} / \mathrm{ml}$ bFGF resulted in a 2.5 -fold increase above basal levels. Transfection of VSMCs with a mutated SRE-CAT plasmid resulted in diminished CAT activity equivalent to that detected in lysates from mock-transfected cells (data not shown). Troglitazone inhibited bFGF-inducible SRECAT activity in a dose-dependent fashion (Fig. 4). In the presence of $1 \mu \mathrm{M}$ troglitazone, bFGF-stimulated SRE-CAT activity was reduced to $73 \pm 4 \%(P=0.08, \mathrm{NS})$ of expression in cells treated with bFGF alone. Troglitazone at 10 and $20 \mu \mathrm{M}$ further inhibited SRE-CAT activity to $43.8 \pm 5.6 \%$ and $24.5 \pm 6.5 \%$ (both $P<0.01$ vs. bFGF alone) of the bFGF-induced effect, respectively.

Troglitazone inhibits SRE function by interfering with the $M A P$ kinase pathway. The transcription factor Elk-1 activates $c$-fos expression through the SRE. Chimeric transcription factors composed of the $\mathrm{NH}_{2}$-terminal DNA binding domain of the yeast GAL protein and the $\mathrm{COOH}$-terminal transactivation domain of Elk-1 have been used by Shaw and colleagues to show that activation of SREs by Elk-1 is dependent on its phosphorylation by MAP kinase $(19,30-32)$. Map kinasedependent Elk-1 specific transactivation can be quantitatively measured by cotransfection of an expression vector expressing the Gal-Elk-1 fusion protein and a reporter construct containing four copies of the GAL4 DNA-binding sites which controls the expression of CAT.

Stimulation of quiescent VSMCs cotransfected with GALElk-1 and GAL4-CAT plasmid with $20 \mathrm{ng} / \mathrm{ml} \mathrm{bFGF} \mathrm{resulted}$ in a $4.4 \pm 1.0$-fold increase in CAT activity relative to cells transfected with the GAL4-CAT reporter construct alone (Fig. 5). In the presence of $1 \mu \mathrm{M}$ troglitazone, bFGF-stimulated

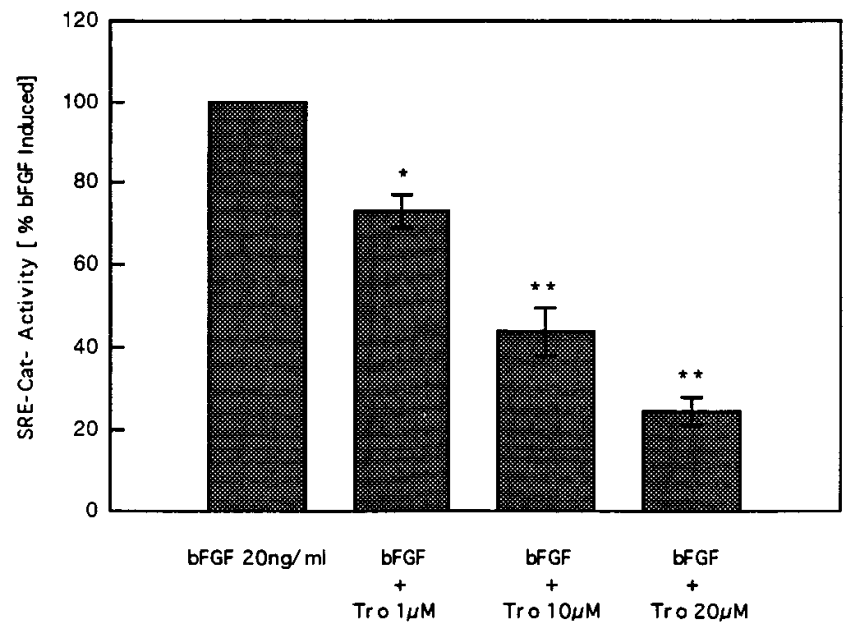

Figure 4. Troglitazone inhibits the activity of the SRE. A plasmid containing two copies of an SRE oligonucleotide and the CAT reporter gene were transfected $(15 \mu \mathrm{g} /$ plate $)$ into VSMCs using the calcium phosphate method. Transfected cells were made quiescent by incubation in DMEM containing $0.4 \%$ FBS for $16 \mathrm{~h}$. Cells were pretreated with troglitazone at 1,10 , and $20 \mu \mathrm{M}$ for $30 \mathrm{~min}$. Quiescent cells were stimulated with $20 \mathrm{ng} / \mathrm{ml}$ bFGF. After $6 \mathrm{~h}$, lysates were prepared from transfected cells and analyzed for CAT activity. To normalize for variability in transfection efficiency, lysates were also analyzed for $\beta$-galactosidase produced by pCH110 (SV40 enhancer$\beta$-galactosidase reporter) that was cotransfected ( $5 \mu \mathrm{g} /$ plate $)$ with SRE-CAT. Data are expressed as CAT activity after normalization to $\beta$-galactosidase activity as the mean $\pm \mathrm{SD}(n=3, * P<0.05 \mathrm{vs.} \mathrm{bFGF}$ induced, $* * P<0.01$ vs. bFGF induced).

GAL-Elk-1-dependent CAT activity was 73.4\% (3.2 \pm 1.2 -fold, NS vs. bFGF alone) of that measured in cells treated with bFGF alone. Troglitazone at 10 and $20 \mu \mathrm{M}$ further inhibited GAL4-CAT activity to $45.5 \%$ (2.0 0 0.6-fold, $P<0.05$ vs. bFGF alone) and $9.3 \%$ (0.41 \pm 0.6 -fold, $P<0.01$ vs. bFGF alone) of the bFGF-stimulated, MAP kinase-dependent effect, respectively. In contrast, when cells were transfected with GAL-Elk $\Delta$ A expression vectors containing mutant GAL-Elkfusion proteins in which MAP kinase phosphorylation sites were internally deleted (Fig. 5), stimulation of quiescent VSMCs with bFGF resulted in no increase in GAL4-CAT activity. This observation is consistent with previous studies demonstrating the dependence of GAL-Elk-1 transactivation function on the phosphorylation of the chimeric transcription factor by MAP kinase (19, 30-32).

Troglitazone inhibition of the MAP kinase pathway occurs downstream of the activation of MAP kinase. Activation of MAP kinase during signal transduction results from its phosphorylation on serine and threonine residues by the dual specificity kinase MAP kinase kinase (MEK) $(33,34)$. In its phosphorylated form, MAP kinase rapidly translocates from the cytoplasm into the nucleus where it can phosphorylate Elk-1 and other nuclear substrates (35-37). An in-gel kinase assay was used to follow the activation of MAP kinase in bFGFstimulated VSMCs. $10 \mathrm{~min}$ after the addition of $20 \mathrm{ng} / \mathrm{ml}$ bFGF, both the p42 and p44 isoforms of MAP kinase exhibited increased activity (Fig. 6). Troglitazone at 1, 10, and $20 \mu \mathrm{M}$ had no effect on bFGF-induced MAP kinase activity. The lack of effect on MAP kinase activation has been consistently observed in four independent in-gel kinase experiments. In con- 


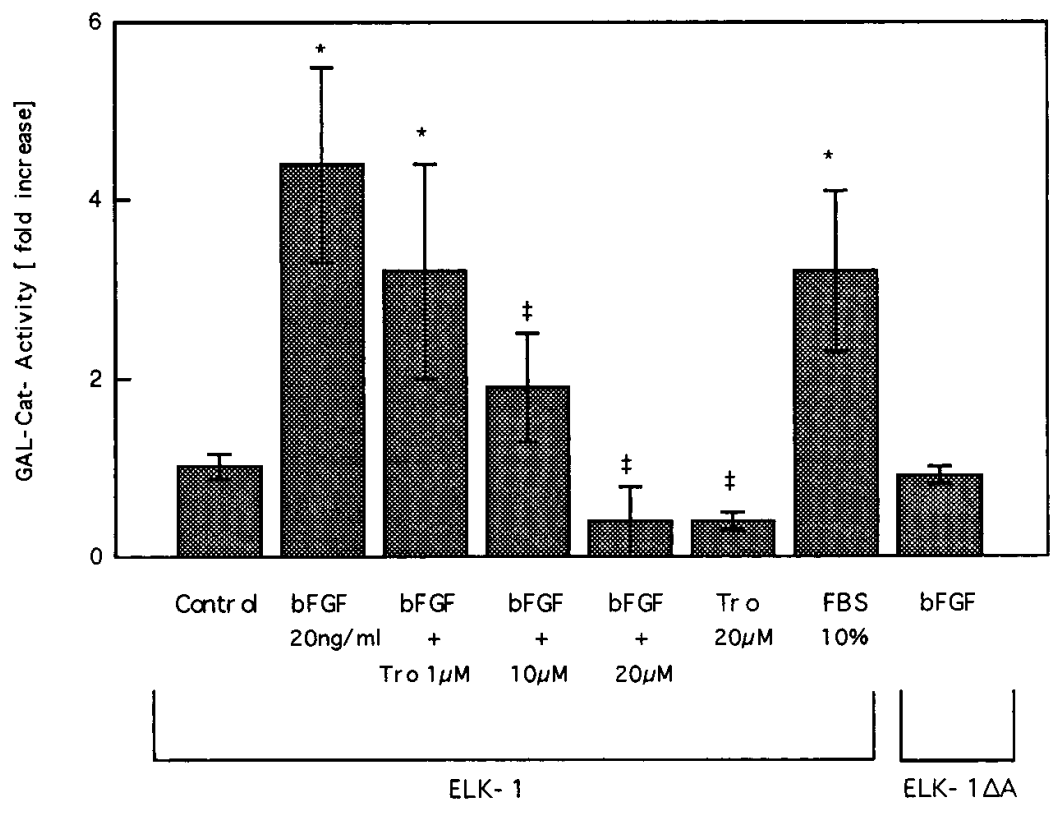

Figure 5. Troglitazone inhibits MAP kinase-dependent transactivation by the GAL-Elk-1 chimeric transcription factor. Quiescent VSMCs were transfected with $7.5 \mu \mathrm{g}$ each of the GAL4-CAT reporter vector and the GAL-Elk-1 expression vector. Subsequent steps were as described in Fig. 4. Data are expressed as CAT activity after normalization to $\beta$-galactosidase activity as means $\pm \mathrm{SD}, n=4, P<0.05$ vs. bFGF induced, ${ }^{\ddagger} P<0.01$ vs. bFGF induced. trast, the MEK inhibitor PD 98059 at 1 and $30 \mu \mathrm{M}$ decreased the level of MAP kinase activation by bFGF. Thus, troglitazone inhibited bFGF-induced, MAP kinase-dependent Elk-1 function (Fig. 5), but had no effect on the inhibition of bFGFinduced MAP kinase activation (Fig. 6). In combination, these findings suggest that troglitazone blocks the MAP kinase pathway at some point after the activation of MAP kinase by MEK, either the phosphorylation of Elk-1 by MAP kinase or the interaction of phosphorylated Elk-1 with other components of the transcriptional machinery at the SRE.

Evidence that MAP kinase is important for $b F G F$-induced DNA synthesis. The MEK inhibitor, PD 98059, inhibited bFGF-induced BrdU incorporation (Fig. 7). This effect was complete at $1 \mu \mathrm{M}$ PD 98059 and was similar at 10 and $30 \mu \mathrm{M}$. There was no effect when PD 98059 was added alone. These results suggest that bFGF-induced growth of VSMCs is dependent on activation of the MAP kinase pathway.

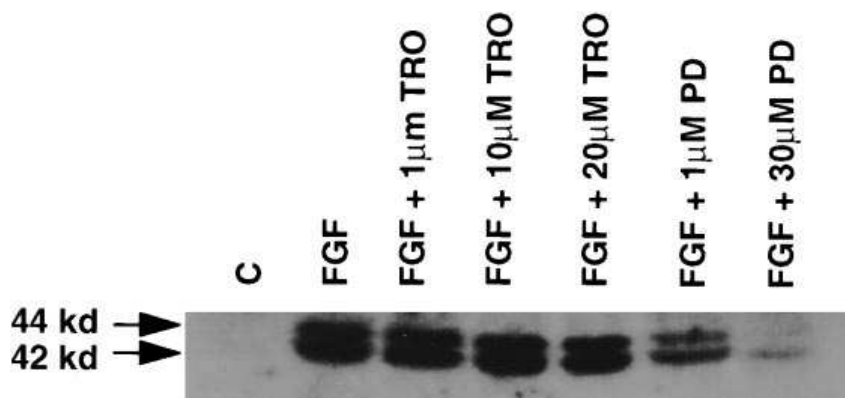

Figure 6. Troglitazone does not affect bFGF-induced activation of MAP kinase. After a 30-min preincubation with 1,10 , and $20 \mu \mathrm{M}$ troglitazone or 1 or $30 \mu \mathrm{M}$ PD 98059, quiescent VSMCs were stimulated with $20 \mathrm{ng} / \mathrm{ml} \mathrm{bFGF}$ for $10 \mathrm{~min}$, cell extracts were prepared, and equal amounts of protein $(5-10 \mu \mathrm{g})$ were separated on $10 \%$ PAGESDS gels containing $0.4 \mathrm{mg} / \mathrm{ml} \mathrm{MBP.} \mathrm{In-gel} \mathrm{kinase} \mathrm{renaturation} \mathrm{as-}$ says were performed and bands corresponding to the 44-kD (ERK1) and 42-kD (ERK2) MAP kinases were visualized by the phosphorylation of MBP. The autoradiogram depicted is representative of those obtained from three independent experiments.
Troglitazone inhibits PDGF-BB-directed migration of VSMCs. The effect of troglitazone on PDGF-BB-directed VSMC migration was examined by performing a modified Boyden chemotaxis assay. PDGF-BB enhanced migration to $27.8 \pm 1.8$ cells $/ \mathrm{HPF}$ in comparison to control, 9.3 \pm 0.6 cells/ HPF $(P<0.01, n=8)$. Troglitazone significantly inhibited the migration of VSMCs that was induced when PDGF-BB (20 ng/ $\mathrm{ml})$ was present in the lower compartment of the transwells (Fig. 8). At $1 \mu \mathrm{M}$ troglitazone, VSMC migration was inhibited by $70 \pm 6 \%(1 \mu \mathrm{M}$ troglitazone + PDGF-BB, $13.3 \pm 1.3$ cells/ HPF, $P<0.01$ vs. PDGF-BB alone, $n=8)$. Maximal inhibition

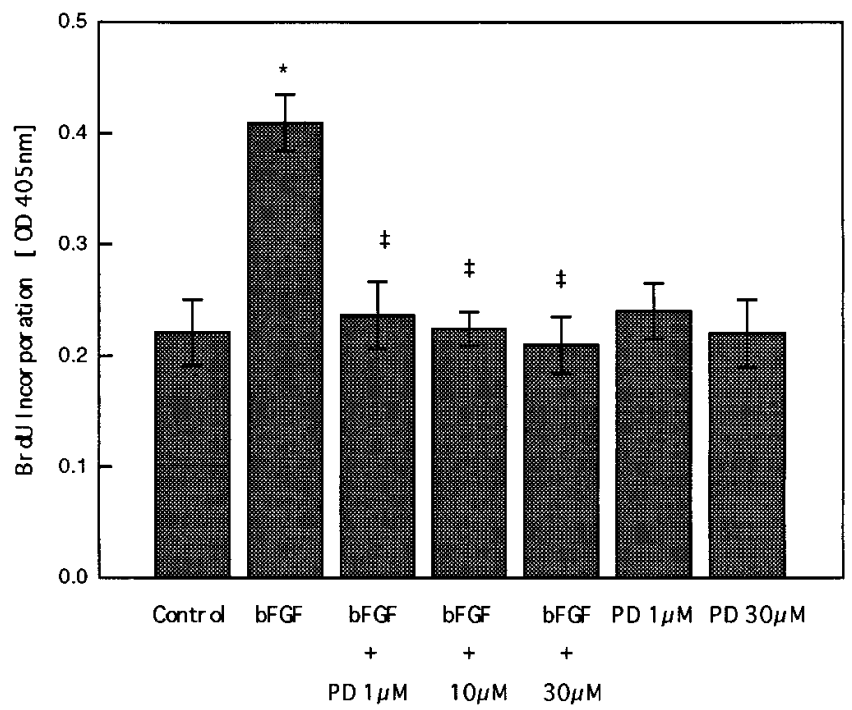

Figure 7. bFGF-induced DNA synthesis in VSMCs is MAP kinase dependent. Quiescent VSMCs were pretreated with 1 or $30 \mu \mathrm{M}$ PD 98059 before stimulation with $20 \mathrm{ng} / \mathrm{ml}$ bFGF for $48 \mathrm{~h}$. BrdU was added at $15 \mu \mathrm{M}$ for the final $4 \mathrm{~h}$ at which time BrdU incorporation was quantitated by ELISA using a commercial kit from Boehringer Mannheim. Data are expressed as mean $\pm \mathrm{SD}\left(n=8,{ }^{*} P<0.05\right.$ vs. Control, ${ }^{\ddagger} P<0.05$ vs. bFGF alone). 


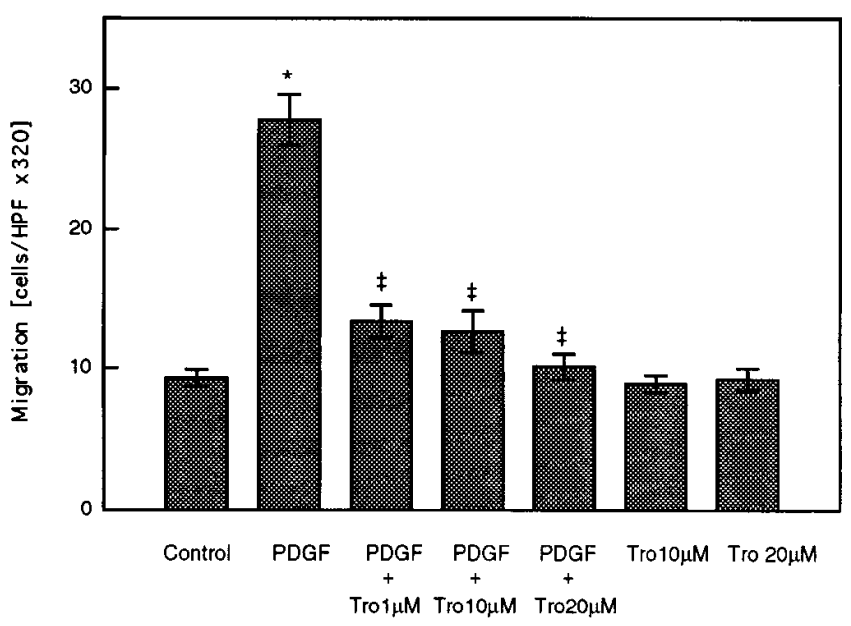

Figure 8. Troglitazone inhibits PDGF-BB-directed migration of VSMC. 4-h migration assays were performed using a modified Boyden chamber seeded with 40,000 cells per well and PDGF-BB $(20 \mu \mathrm{g} /$ $\mathrm{ml})$ as the chemoattractant. Data are expressed as mean $\pm \mathrm{SD}(n=6$, ${ }^{*} P<0.05$ vs. Control, ${ }^{\ddagger} P<0.05$ vs. PDGF-BB alone) .

(93.4 $\pm 4.4 \%, P<0.001)$ of VSMC migration was observed with $20 \mu \mathrm{M}$ troglitazone, $9.2 \pm 0.7$ cells/HPF.

Troglitazone inhibits neointimal thickening after aortic balloon injury. Our in vitro experiments revealed that troglitazone potently inhibited both bFGF-stimulated VSMC proliferation and PDGF-BB-induced cell migration. To determine whether these effects were applicable in vivo to inhibit neointima formation after arterial injury, troglitazone was adminis- tered as a dietary supplement before balloon catheterization of the aorta. Male Sprague-Dawley rats weighing 280-300 grams were divided into two groups; one received a 4-gram troglitazone/kg chow supplement while the other group's diet was unchanged. After $3 \mathrm{~d}$, all animals received balloon injury to the aorta extending caudal to the renal artery and rostral to the left main carotid artery. $14 \mathrm{~d}$ after injury, aortas were harvested, paraffin sectioned, and stained with hematoxylin and eosin.

Troglitazone significantly inhibited BrdU incorporation at $48 \mathrm{~h}$ and the accumulation of neointimal smooth muscle cells in the injured vessel at $14 \mathrm{~d}$. In vivo medial VSMC proliferation as assessed by in situ BrdU labeling was inhibited by $\sim 66 \%(3.4 \pm 0.7 \%$ in troglitazone-treated vs. $9.9 \pm 0.2 \%$ in normal chow controls, $P<0.01, n=8$ ) after injury (data not shown). Several of the rings from troglitazone-treated animals displayed virtually no discernible neointima, whereas all rings from normal chow controls had extensive neointimal thickening (Fig. 9, $A$ and $B$ ). Quantitative analysis of injured aortic segments (Fig. $9 C$ ) showed that troglitazone-fed animals had $\sim 62 \%$ less neointimal/media area ratio than vehicletreated controls $(0.0625 \pm 0.0149$ vs. $0.165 \pm 0.0092, n=14$ for troglitazone-treated, $n=13$ for vehicle-treated controls, $P<$ 0.0001). Animals on troglitazone exhibited similar weight gain and exhibited no other evidence of toxicity when compared with normal chow controls.

\section{Discussion}

The present investigation demonstrates that troglitazone inhibited bFGF-induced DNA synthesis and $c$-fos induction and
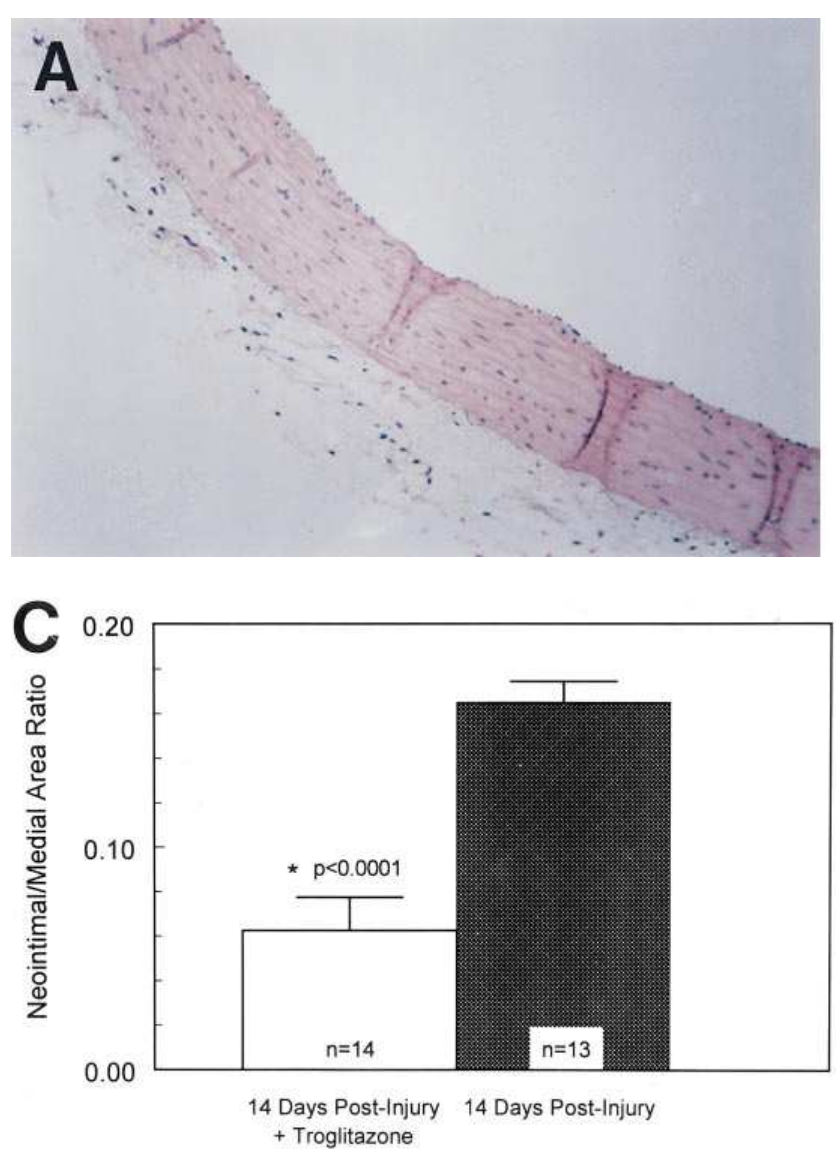

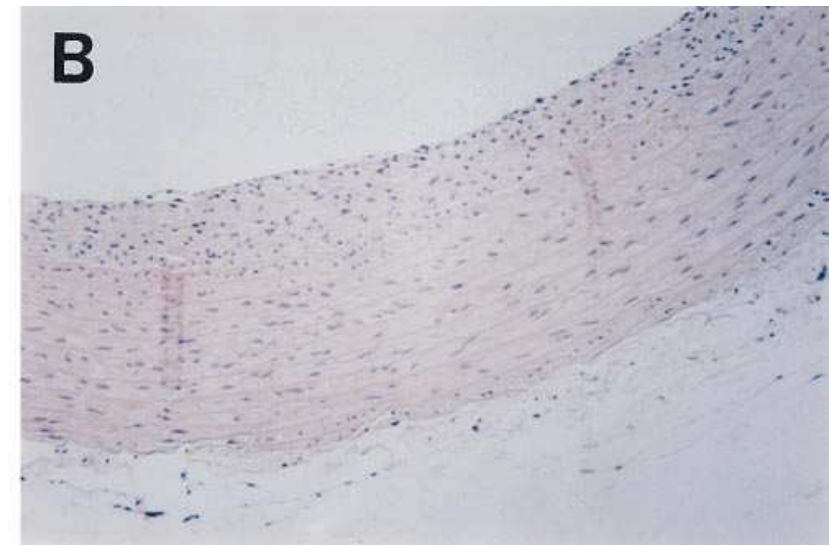

Figure 9. Troglitazone inhibits the accumulation of intimal smooth muscle cells $14 \mathrm{~d}$ after balloon catheter injury of rat aorta. The animals were administered 4 grams troglitazone $/ \mathrm{kg}$ chow starting $3 \mathrm{~d}$ before injury and continued throughout the $14-d$ postinjury period.

Representative hematoxylin and eosin-stained cross sections from $(A)$ troglitazone-fed and $(B)$ chow-fed only animals are shown. Both, $\times 100$. $(C)$ The image of each aorta cross section $14 \mathrm{~d}$ after injury $(14$ troglitazone-treated and 13 chow-fed only animals) was projected on a monitor. The cross-sectional areas of the intima and the media were measured and are presented as ratios (mean \pm SEM), ${ }^{*} P<0.0001$ by unpaired $t$ test. 
PDGF-BB-induced migration, all of which are behaviors of VSMCs critical to the processes of restenosis and atherosclerosis. Induction of $c$-fos occurs in VSMCs within minutes after balloon injury (38); this is accompanied by induction of bFGF and PDGF-BB expression (10). Thus, in vitro data are consistent with our observation that troglitazone inhibited the intimal hyperplasia that results from balloon injury to arterial endothelium in the rat. These results indicate that the cellular effects of troglitazone on bFGF-mediated VSMC proliferation and PDGF-BB-directed migration are highly relevant in vivo.

Thiazolidinediones inhibit tyrosine kinase-dependent growth factor action in VSMC: bFGF and PDGF, as reported herein, and insulin and EGF, as reported previously $(18,39)$. These agents were shown to inhibit EGF-induced receptor autophosphorylation in BALB/MK and A431 cells (40). In contrast, they do not inhibit insulin receptor phosphorylation, a step which is crucial in insulin's action to promote glucose uptake in skeletal muscle and adipose tissue $(41,42)$. Thus, their major action is not likely directed at phosphorylation of growth factor receptors. Ciglitazone, another thiazolidinedione analogue, inhibited PDGF-induced calcium mobilization (43), and we have demonstrated that pioglitazone is a calcium channel blocker and probably lowers blood pressure by this mechanism (44). However, growth inhibition occurs at concentrations 20-fold lower than that required to inhibit calcium channels. In addition, bFGF-induced growth is not calcium dependent, since point mutations in the bFGF receptor that abolished phosphatidylinositol turnover and intracellular calcium transients had no effect on bFGF-induced mitogenesis (45). Therefore, other mechanisms are likely responsible for the antiproliferative properties of thiazolidinediones.

One common signaling pathway that is activated when mitogenic growth factors engage their receptors is the MAP kinase pathway, $(33,34)$ which involves $\mathrm{Ras} \rightarrow \mathrm{Raf} \rightarrow \mathrm{MEK} \rightarrow$ MAP kinase $\rightarrow$ ELK $-1 \rightarrow$ SRE $\rightarrow c$-fos. We have demonstrated that this pathway is important for VSMC growth, since the MEK kinase inhibitor, PD 98059, prevented bFGF-induced DNA synthesis in VSMCs $(46,47)$. The observation that troglitazone inhibited bFGF-induced SRE-CAT activity further implicated this pathway, since MAP kinase directly activates the transcription factor, Elk-1, which binds to the SRE, facilitating induction of $c$-fos $(19,30-32)$. SRE function appeared to be less sensitive to inhibition by troglitazone ( $\sim 27 \%$ inhibition at $1 \mu \mathrm{M})$ than $c$-fos mRNA levels $(>80 \%$ inhibition at $1 \mu \mathrm{M})$. The differential sensitivity to troglitazone detected by these two different assays could be the result of the high copy numbers of SRE elements introduced into a cell by transient transfection, as compared with the single SRE present in each of the two copies of the endogenous c-fos gene.

Similar to our results, bFGF activates SRE by two- to threefold in other systems (48). The finding that troglitazone inhibits SRE function suggests that transcriptional activation of $c$-fos is inhibited. If reduced $c$-fos mRNA levels were the result solely of posttranscriptional effects of troglitazone to destabilize $c$-fos mRNA, then there would likely be no effect on SRE function. This result is significant because a related thiazolidinedione, pioglitazone, has been reported to regulate GLUT 1 and GLUT 4 mRNA levels through a posttranscriptional mechanism (49). MAP kinase-dependent transactivation function of the GAL-Elk-1 chimeric transcription factor was also inhibited by troglitazone. This result strongly suggests that the observed inhibition of bFGF-induced $c$-fos mRNA ex- pression and SRE-CAT activity by troglitazone results from its effect on MAP kinase-dependent Elk-1 activity at the $c$-fos promoter.

The steps in tyrosine kinase growth factor receptor-mediated signal transduction leading to MAP kinase activation have been well-characterized $(33,34)$. Engagement of the growth factor receptor activates the intracellular tyrosine kinase domain which autophosphorylates receptor tyrosine residues that serve as specific binding sites for the recruitment of other signaling proteins containing src homology 2 domains (SH2), such as the adaptor protein GRB2 that promotes the interaction of guanine nucleotide releasing proteins with Ras leading to its activation. This event triggers the activation of multiple cytoplasmic serine-threonine protein kinases in cascade fashion. Raf-1 kinase after its activation through Ras phosphorylates MEK which in its activated form then phosphorylates and activates MAP kinase. Interestingly, troglitazone had no effect on the bFGF-induced activation of MAP kinase by MEK. Therefore, inhibition of the MAP kinase pathway by troglitazone appears to occur at some signaling step downstream from the point where the MEK inhibitor PD 98059 prevents MAP kinase activation by MEK.

Currently, the events that occur downstream of MAP kinase activation leading to the modification of nuclear transcription factors, such as Elk-1, and the regulation of gene expression, such as $c$-fos, are obscure. Within minutes of growth factor stimulation, MAP kinase translocates into the nucleus and there is increased phosphorylation of Elk-1 at MAP kinase sites $(19,30-32)$. The molecular mechanism by which MAP kinase undergoes nuclear translocation is not understood. Equally obscure are any molecular events which may be required for translocated MAP kinase to target Elk-1 in the nucleus and phosphorylate it. More detailed studies are required to elucidate these complex steps to determine whether troglitazone interferes with these nuclear events.

We also demonstrated that troglitazone inhibits PDGFinduced VSMC migration. The signal transduction mechanisms which mediate migration are unknown, although a calcium-dependent pathway involving CAM-kinase has been proposed $(5,50)$. We have reported recently that the MEK inhibitor PD 98059 inhibits PDGF-induced and angiotensin IIinduced VSMC migration (51), suggesting the involvement of the MAP kinase pathway. Taken together, our data suggest that inhibition of the MAP kinase pathway by troglitazone, potentially at the nuclear level, inhibits both migration and growth of VSMCs.

Strategies designed to inhibit VSMC proliferation and migration generally attenuate intimal hyperplasia in the injured rat artery and restenosis in injured vessels of larger animal models. Antibodies against PDGF and FGF $(3,7)$, targeted killing of proliferating VSMC (using bFGF conjugated to saporin) (52), overexpression of inhibitors of cell cycle progression such as the p21 protein (53) and the retinoblastoma $(\mathrm{Rb})$ gene (12), or antisense to cell cyclins (11) or proliferating cell nuclear antigen, PCNA (54), all significantly inhibited the intimal proliferative response after endothelial denudation. More recently, administration of a matrix metalloproteinase inhibitor (55), mithramycin (56), and taxol, which prevents VSMC growth and migration by disassembly of cell microtubules, has also been demonstrated to prevent the intimal fibroproliferative response (28). Of all of these possible approaches, only the anticancer agents, taxol and mithramycin, are available for 
clinical use. Plasma levels of taxol approximately two orders of magnitude lower than that achieved to treat malignancy appeared effective at inhibition of neointimal proliferation in the rat and, thus, may be useful for restenosis in humans (28).

The demonstration that troglitazone inhibits the development of the neointima raises strong interest in its potential utility to inhibit human restenosis. The finding that troglitazone inhibits multiple growth factors, many which can act through the MAP kinase pathway, may have important therapeutic implication since both restenosis and atherosclerosis are complex processes governed by the interaction of a variety of growth factors. Currently, this thiazolidinedione is being widely tested as an oral antidiabetic agent, which improves glucose control by enhancement of insulin-mediated glucose uptake into skeletal muscle and adipose tissue and by suppression of hepatic glucose production (17). Troglitazone also decreases circulating triglycerides and blood pressure, which is highly useful in insulin-resistant patients who are commonly hypertriglyceridemic and hypertensive (17). The availability of a safe, oral agent which inhibits the actions of numerous growth factors on VSMCs holds promise as an antirestenotic agent, although investigation in larger animal models is necessary.

Whether thiazolidinediones will prevent the development of atherosclerosis is another critical question raised by these studies. VSMC proliferation is an intermediate event in the atherosclerotic process, which follows endothelial cell damage and the deposition of fatty streaks in the vessel wall and results in the formation of the organized atherosclerotic plaque (57). It is unknown whether agents which inhibit VSMC growth prevent the development of advanced atherosclerotic lesions; thiazolidinediones may be useful agents to address this question. This issue is particularly relevant to the diabetic who has a two- to fourfold increased incidence of coronary artery disease (CAD) compared with the nondiabetic (58). Patients with NIDDM develop CAD even before the development of hyperglycemia, suggesting that there are common risk factors for CAD and NIDDM (59). Insulin resistance and hyperinsulinemia have been implicated as possible common risk factors (60). Insulin has been suggested to promote VSMC growth (61); and although it is a weak mitogen alone, in physiologic concentrations it promotes the effects of PDGF and other growth factors in VSMC (62). Troglitazone improves the insulin-resistant state by as much as $80 \%$ in patients at high risk for NIDDM and reduces circulating insulin levels (63). Therefore, thiazolidinediones may not only be useful for prevention of NIDDM, but their ability to alter the metabolic milieu, as well as their direct vascular effects, may be important for prevention of CAD in insulin-resistant subjects.

\section{Acknowledgments}

We thank Denise Edwards and Janie Teran for their secretarial contributions. We thank Thomas Valiquett, Dean Lockwood, and Randy Witcomb of Parke-Davis for their generosity in providing troglitazone.

This study was supported by a Specialized Center for Research Grant in Hypertension from the National Heart Lung and Blood Institute (1P50-HL4404) to W.A. Hsueh and a Research Grant from the American Diabetes Association (ADA 96) to R.E. Law.

\section{References}

1. Ross, R. 1993. The pathogenesis of atherosclerosis: a perspective for the 1990s. Nature (Lond.). 362:801-809.
2. Gerstendorst, G.R., H.E.J. Seppa, H.K. Kleinman, and G.R. Martin. 1981. Attachment of smooth muscle cells to collagen and their migration toward platelet-derived growth factor. Proc. Natl. Acad. Sci. USA. 78:3669-3672.

3. Ferns, G.A., E.W. Raines, K.H. Sprugel, A.S. Montani, M.A. Reidy, and R. Ross. 1991. Inhibition of neointimal smooth muscle accumulation after angioplasty with an antibody to PDGF. Science (Wash. DC). 253:1129-1132.

4. Jawien, A., D.F. Bowen-Pope, V. Lindner, S.M. Schwartz, and A.W. Clowes. 1992. Platelet-derived growth factor promotes smooth muscle migration and intimal thickening in a rat model of balloon angioplasty. J. Clin. Invest. 89:507-511.

5. Bilato, C., R.R. Pauly, G. Metillo, R. Monicone, D. Gorelick-Feldman, Y.A. Gluzband, S.J. Sollot, B. Ziman, E.G. Lakatta, and M.T. Crow. 1995. Intracellular signaling pathways required for rat vascular smooth muscle cell migration. J. Clin. Invest. 96:1905-1915.

6. Lindner, V., D.A. Lappi, A. Baird, R.A. Majack, and M.A. Reidy. 1991. Role of basic fibroblast growth factor in vascular lesion formation. Circ. Res. 68: 106-113.

7. Lindner, V., and M.A. Reidy. 1991. Proliferation of smooth muscle cells after vascular injury is inhibited by an antibody against basic fibroblast growth factor. Proc. Natl. Acad. Sci. USA. 88:3739-3743.

8. Libby, P., S.J. Warner, R.N. Salmon, and L.K. Birinyi. 1988. Production of platelet-derived growth factor-like mitogen by smooth muscle cells from human atheroma. N. Engl. J. Med. 318:1493-1498.

9. Majesky, M.W., M.A. Reidy, D.F. Bowen-Pope, C.E. Hart, J.N. Wilcox, and S.M. Schwartz. 1990. PDGF ligand and receptor gene expression during repair of arterial injury. J. Cell Biol. 111:2149-2158.

10. Miano, J.M., N. Vlasik, R.R. Tota, and M.B. Stemerman. 1993. Smooth muscle cell immediate-early gene and growth factor activation follows vascular injury. Arterioscler. Thromb. 13:211-219.

11. Morishita, R., G.H. Gibbons, K.E. Ellison, M. Najajima, H. von der Leyen, L. Zhang, Y. Kaneda, T. Ogihara, and V.J. Dzau. 1994. Intimal hyperplasia after vascular injury is inhibited by antisense cdk 2 kinase oligonucleotides. J. Clin. Invest. 93:1458-1464.

12. Chang, M.W., E. Barr, J. Seltzer, Y.Q. Jian, G.J. Nabel, E.G. Nabel, M.S. Parmacek, and J.M. Leiden. 1995. Cytostatic gene therapy for vascular proliferative disorders with a constitutively active form of the retinoblastoma gene product. Science (Wash. DC). 267:518-522.

13. Fujiwara, T., S. Yoshioka, T. Yoshioka, I. Ushiyama, and H. Horikoshi. 1988. Characterization of new oral antidiabetic agent CS-045. Diabetes. 37: 1549-1558.

14. Lee, M.K., D.G. Phillip, M. Khoursheed, K.M. Gao, A.R. Moossa, and J.M. Olefsky. 1994. Metabolic effects of troglitazone on fructose-induced insulin resistance in the rat. Diabetes. 43:1435-1439.

15. Eldershaw, T.P.D., S. Rattigan, M.A. Cawthorne, R.E. Buckingham, E.Q. Colquhoun, and M.G. Clark. 1995. Treatment with the thiazolidinedione (BRL 49653) decreased insulin resistance in obese Zucker hindlimb. Horm. Metab. Res. 27:169-172.

16. Iwamato, I., T. Kuzuya, A. Matsuda, S. Kumakura, G. Inooka, and I Shiraishi. 1991. Effect of new oral antidiabetic agent CS-045 on glucose tolerance and insulin secretion in patients with NIDDM. Diabetes Care. 14:10831086.

17. Nolan, J.J., B. Ludvik, P. Beerdsen, M. Joyce, and J. Olefsky. 1994. Improvement in glucose tolerance and insulin resistance in obese subjects treated with troglitazone. N. Engl. J. Med. 331:1188-1193.

18. Dubey, R.K., H.Y. Zhang, S.R. Reddy, M.A. Boegehold, and T.A. Kotchen. 1993. Pioglitazone attenuates hypertension and inhibits growth of renal arteriolar smooth muscle in rats. Am. J. Physiol. R726-R732.

19. Kortenjann, M., O. Thomae, and P.E. Shaw. 1994. Inhibition of v-rafdependent $c$-fos expression and transformation by a kinase-defective mutant of the mitogen-activated protein kinase Erk2. Mol. Cell. Biol. 14:4815-4824.

20. Twentyman, P.R., and M. Luscombe. 1987. A study of some variables in tetrazolium dye (MTT) based assay for cell growth and chemosensitivity. Br. J. Cancer. 56:279-285.

21. Van de Loosdrecht, A.A., R.H.J. Beelen, G.J. Ossenkoppele, M.G. Broekhoven, and M.M.A.C. Langenhuijsen. 1994. A tetrazolium-based colorimetric MTT assay to quantitate human monocyte mediated cytotoxicity against leukemic cells from cell lines and patients with acute myeloid leukemia. J. Immunol. Methods. 174:311-320.

22. Chomczynski, P.S., and N. Sacchi. 1989. Single step method of RNA isolation by acid guanidinium thiocyanate-phenol-chloroform extraction. Anal. Biochem. 162:156-159.

23. Harpold, M.M., R.M. Evans, M. Saidtt-Georgieff, and J.E. Darnell. 1979. Production of mRNA in Chinese hamster cells; relationship of the rate of synthesis to the cytoplasmic concentration of nine specific mRNA sequences. Cell. 17:1025-1035.

24. Sleigh, M.J. 1986. A nonchromatographic assay for expression of the chloramphenicol acetyl transferase gene in eukaryotic cells. Anal. Biochem. 156:251-256.

25. Miller, J.H. 1972. In Experiments in Molecular Genetics. J.H. Miller, editor. Cold Spring Harbor Laboratory, New York. 352-355.

26. Clowes, A.W., M.A. Reidy, and M.M. Clowes. 1983. Kinetics of cellular proliferation after arterial injury. I. Smooth muscle growth in the absence of endothelium. Lab. Invest. 49:327-333. 
27. Katuka, T., J.W. Currier, C.C. Haudenschild, T.J. Ryan, and D.P. Faxon. 1994. Differences in compensatory vessel enlargement, not intimal formation, account for restenosis after angioplasty in the hypercholesterolemic rabbit model. Circulation. 89:2809-2815.

28. Lakatta, E.G., E.K. Rowinsky, and J.L. Kinsella. 1995. Taxol inhibits neointimal smooth muscle cell accumulation after angioplasty in the rat. J. Clin. Invest. 95:1869-1876.

28a. Treisman, R. 1995. Journey to the surface of the cell: Fos regulation and the SRE. EMBO (Eur. Mol. Biol. Organ.) J. 14:4905-4913.

29. Janknecht, R., M.A. Cahil, and A. Nordhem. 1995. Signal integration at the $c$-fos promoter. Carcinogenesis. 16:443-450.

30. Gille, H., A.D. Sharrocks, and P.E. Shaw. 1992. Phosphorylation of transcription factor p62 ${ }^{\mathrm{TCF}}$ by MAP kinase stimulates ternary complex formation at c-fos promoter. Nature (Lond.). 358:414-417.

31. Gille, H., M. Kortenjann, O. Thomae, C. Moomaw, C. Slaughter, M.H. Cobb, and P.E. Shaw. 1995. ERK phosphorylation potentiates Elk-1-mediated ternary complex formation and transactivation. EMBO (Eur. Mol. Biol. Organ.) J. 14:951-962.

32. Gille, H., M. Kortenjann, T. Strahl, and P.E. Shaw. 1996. Phosphorylation-dependent formation of a quaternary complex at the $c$-fos SRE. Mol. Cell. Biol. 16:1094-1102.

33. Davis, D.J. 1993. The mitogen-activated protein kinase signal transduction pathway. J. Biol. Chem. 268:14553-14556.

34. Seger, R., and E.G. Krebs. 1995. The MAPK signaling cascade. FASEB (Fed. Am. Soc. Exp. Biol.) J. 9:726-735.

35. Chen, R.H., C. Sarnecki, and J. Blenis. 1992. Nuclear localization and regulation of ERK-and RSK-encoded protein kinases. Mol. Cell. Biol. 12:915-927.

36. Leonormand, P., C. Sardet, G. L'Allemain, and A. Brunet. 1993. Growth factors induce nuclear translocation MAP kinases ( $\mathrm{p}^{\mathrm{mapk}}$ and $\left.\mathrm{p} 45\right)$ but not their activator MAP kinase kinase $\left(\mathrm{p} 45^{\mathrm{mapk}}\right)$ in fibroblast. J. Cell Biol. 122:1079-1088.

37. Gonzalez, F.A., A. Seth, D.L. Raden, D.S. Bowman, F.S. Fay, and R.J. Davis. 1993. Serum-induced translocation of mitogen activated protein kinase to the cell surface ruffling membrane and the nucleus. J. Cell Biol. 122:10891101.

38. Miano, J.M., N. Vlasic, R.R. Torta, and M.B. Stemerman. 1993. Localization of Fos and Jun protein in rat aortic smooth muscle cells after vascular injury. Am. J. Pathol. 142:715-724.

39. Law, R.E., X.P. Xi, and W.A. Hsueh. 1995. Troglitazone inhibits insulin, EGF, and PDGF mitogenic signal transduction in A10 vascular smooth muscle (VSM) and mesangial cells. Hypertension (Dallas). 26:553a. (Abstr.)

40. Geissler, J.F., P. Traxler, U. Regenass, B.J. Murray, J.L. Roesel, T. Myer, E. McGlynn, A. Storni, and N.B. Lydon. 1990. Biochemical and biological activity of a novel class of tyrosine protein kinase inhibitors. J. Biol. Chem. 285:22255-22281.

41. Kobayashi, M., M. Iwanishi, K. Egawa, and Y. Shigeta. 1992. Pioglitazone increase insulin sensitivity by activating insulin receptor kinase. Diabetes. 41:476-483.

42. Iwanishi, M., and M. Kobayashi. 1993. Effect of pioglitazone on insulin receptors of skeletal muscles from high-fat-fed rats. Metab. Clin. Exp. 42:10171021.

43. Pershadsingh, H.A., J. Szollosi, S. Benson, W.C. Hyun, B.G. Feuerstein, and T.W. Kurtz. 1993. Effects of Ciglitazone on blood pressure and intracellular calcium metabolism. Hypertension (Dallas). 21:1020-1023.

44. Buchanan, T.A., W.P. Meehan, Y.Y. Jeng, D. Yang, T.M. Chan, J.L. Nadler, S. Scott, R.K. Rude, and W.A. Hsueh. 1995. Blood pressure lowering by Pioglitazone. Evidence for a direct vascular effect. J. Clin. Invest. 96:354-360.

45. Peters, K.G., J. Marie, E. Wilson, H.E. Ives, J. Escobedo, M. DelRoasaio, D. Mirada, and L.T. Williams. 1992. Point mutation of an FGF receptor abolishes phosphatidylinositol turnover and $\mathrm{Ca}^{2}$ flux but not mitogenesis. $\mathrm{Na}$ - ture (Lond.). 358:678-681

46. Alessi, D.R., A. Cuenda, P. Cohen, D.T. Dubley, and A.R. Saltiel. 1995. PD-098059 is a specific inhibitor of the activation of mitogen-activated protein kinase in vitro and in vivo. J. Biol. Chem. 270:27489-27494.

47. Dudley, D.T., L. Pang, S.J. Decker, A.J. Bridges, and A.R. Saltiel. 1995. A synthetic inhibitor of the mitogen-activated protein kinase cascade. Proc. Natl. Acad. Sci. USA. 92:7686-7689.

48. Parker, T.G., K.L. Chow, R.J. Schwartz, and M.D. Schneider. 1992. Positive and negative control of the skeletal $\alpha$-actin promoter in cardiac muscle. $J$. Biol. Chem. 267:3343-3350.

49. Sandouk, T., D. Reda, and C. Hofmann. 1993. The antidiabetic agent pioglitazone increases expression of glucose transporters in 3-TF442A cells by increasing messenger ribonucleic acid transcript stability. Endocrinology. 133: 352-359.

50. Pauly, R.R., C. Bilato, S.J. Sollott, R. Monticone, P.T. Kelly, E.G. Lakatta, and M.T. Crow. 1995. Role of calcium/calmodulin-dependent protein kinase II in the regulation of vascular smooth muscle cell migration. Circulation. 91:1107-1115.

51. Graf, K., X.-P. Xi, J. Tian, R.E. Law, and W.A. Hsueh. 1996. MAP kinase-activation is involved in angiotensin II and PDGF-directed migration by vascular smooth muscle cell. 50th Scientific Sessions, Council for High Blood Pressure. (Abstr.)

52. Casscells, W., D.A. Kappi, B.B. Olwin, C. Wai, M. Sieman, E.H. Speir, J. Sasse, and A. Baird. 1992. Elimination of smooth muscle cells in experimental restenosis: targeting of fibroblast growth factor receptors. Proc. Natl. Acad. Sci. USA. 89:7159-7163.

53. Chang, M.W., E. Barr, M.M. Lu, K. Barton, and J.M. Leiden. 1995. Adenovirus-mediated over-expression of the cyclin/cyclin-dependent kinase inhibitor, p21 inhibits vascular smooth muscle cell proliferation and neointima formation in the rat carotid artery model of balloon angioplasty. J. Clin. Invest. 96: $2260-2268$.

54. Simmons, M., E.R. Edelman, and R.D. Rosenberg. 1994. Antisense proliferating cell nuclear antigen oligonucleotides inhibit intimal hyperplasia in a rat carotid artery injury model. J. Clin. Invest. 93:2351-2356.

55. Zempo, N., N. Koyama, R.D. Kenagy, H.J. Lea, and A.W. Clowes. 1996. Regulation of vascular smooth muscle cell migration and proliferation in vitro and in injured rat arteries by a synthetic matrix metalloproteinase inhibitor. $\mathrm{Ar}$ terioscler. Thromb. Vasc. Biol. 16:28-33.

56. Chen, S.J., Y.F. Chen, D.M. Miller, H. Li, and S. Oparil. 1994. Mithramycin inhibits myointimal proliferation after balloon injury of the rat carotid artery in vivo. Circulation. 90:2468-2473.

57. Schwartz, S.M., D. DeBois, and E.R.M. O'Brien. 1995. The intima: soil for atherosclerosis and restenosis. Circ. Res. 77:445-465.

58. Savage, P.J. 1996. Cardiovascular complications of diabetes mellitus: what we know and what we need to know about their prevention. Ann. Intern. Med. 124:123-126.

59. Jarrett, R.J., and M.J. Shiplsy. 1988. Type 2 (non-insulin-dependent) diabetes mellitus and cardiovascular disease: putative association via common antecedent. Further evidence from the Whitehall study. Diabetologia. 31:737-740.

60. Hsueh, W.A., R.E. Law, M. Saad, J. Dy, E. Feener, and G. King. 1996. Insulin resistance and macrovascular disease. Curr. Opin. Endocrinol. \& Metab. 3:346-354.

61. Stout, R.W. 1990. Insulin and atheroma: 20 year perspective. Diabetes Care. 1:631-654.

62. Banskota, N.K., R. Taub, K. Zellner, and G.L. King. 1989. Insulin, IGF-1 and PDGF interact additively in the activation of protooncogene c-myc and cellular proliferation in cultured BSMC. Mol. Endocrinol. 3:1183-1199.

63. Berkowitz, K., R. Peters, S. Kjos, M. Dunn, A. Xiang, J. Goico, A. Marroquin, S. Azen, and T. Buchanan. 1996. Effects of troglitazone on insulin sensitivity and B-cell function in women with prior gestational diabetes. Diabetes. 45:57A. 